\title{
Transmitting Local Cultural Knowledge through English as Foreign Language (EFL) Learning as a Means of Fostering "Unity in Diversity"
}

\author{
Yeny Prastiwi \\ Deakin University \\ Melbourne, Australia
}

Doi:10.5901/ajis.2013.v2n3p507

\begin{abstract}
Lack of appreciation of local culture on the part of the public is a continuing concern for many governments. In the Indonesian context, the national and regional governments have a vision to preserve local cultural knowledge as a means to foster the spirit of Unity in Diversity [Bhinneka Tunggal Ika], Indonesia's national motto. Education has been seen as an appropriate forum for fulfilling this aim, and local culture has been incorporated into various school subjects in the curriculum. It has been the policy of the Ministry of National Education that primary school teachers of English as a foreign language (EFL) be responsible for giving students the ability to use English and also an understanding of local culture. Interpretation of policy varies depending on location, however, and may also depend on the individual characteristics and background of teachers. This paper, which is based on a case study conducted in Solo, Central Java, Indonesia, will discuss the ways in which primary EFL teachers contribute to the maintenance of local cultural knowledge. While it has been suggested that language learning is enhanced by study of the culture associated with it (see, for example, Risager, 2007), this paper will argue that learning English as the target language is not always corresponding with learning the culture of the target language (C2). As seen from the students' mastery of English in two different primary schools in Solo, Central Java, Indonesia is supported by using the language to teach about local culture, such as through traditional folktales translated into English. It concludes that the use of local cultural material in the teaching of English as a foreign language serves a dual purpose: supporting mastery of the target language (L2) while also enabling teachers to fulfill their obligation to teach about local culture (C1). The data here presented were obtained through semi-structured interviews with primary EFL teachers and students at one public school and one private school in Solo, Central Java, Indonesia. Using teachers' lesson plans related to the use of folktales as medium for teaching EFL as well as fostering the spirit of 'unity in diversity' amongst the students was another significant instrument to investigate and to collect data about their teaching practice and pictures were considered the most appropriate ones for obtaining students' response.
\end{abstract}

Key words: local culture knowledge; EFL; Indonesia; primary education

\section{Background}

This paper is part of a larger ongoing research paper that I am conducting at present. This paper would like to argue the premise saying learning EFL always associated with learning the culture of the target language. In some respects, learning English as the target language (L2) in the Indonesian context is not always equivalent with learning the culture of the target language (C2). The Indonesian government through its constitutions recommends that education sector should participate in preserving local culture. For this reason, teachers including EFL teachers should make use of EFL teachinglearning process as one of ways to preserve local cultural knowledge particularly within the young generations.

Because of the importance of English as a world language, the Indonesian government supports English as the main foreign language taught in schools. English has, in fact, been widely taught since Indonesia achieved independence in1945 because it was seen as a 'neutral' language following the end of colonization by the Dutch. At present, English is taught from junior high school to university level. To encourage greater participation in education, the government has supported the teaching of the English language education at the primary level since 1994. English remains optional at the primary level, and local content is mandated as part of EFL study at this level. This aims to produce school graduates who are competent in basic English and who have absorbed local cultural knowledge at the same time. Most primary school EFL teachers in Solo, Indonesia choose to incorporate Indonesian folktales into English language lessons as a means of complying with government regulations. Kirkpatrick (2008), who studied English teaching in Indonesia, noted that Indonesian students tend to communicate in English when discussing local cultural information with foreigners (English speakers). This suggests that an approach that is sensitive to local culture may be beneficial for English language education in Indonesia. 
This approach has been taken by a number of EFL textbook authors for the primary level. These texts often contain local cultural presented in English (Jakarta Post, 2011). Many EFL textbooks for the primary level make use of Indonesian folktales which represent a certain region of the country. Not all primary school EFL teachers in Solo, Indonesia use this kind of textbook however, including the two teachers who took part in this study.

The use of EFL textbooks which incorporate Indonesian folktales in translation seems to accommodate the government's aim to produce school graduates who are able to use basic English and who have local cultural knowledge. This idea has been established through various policy documents. The Constitution of the National Education System 2003 Article 1, paragraph 2 defines national education as follows, "National education is an education system based on Pancasila (the national foundation of the Indonesian state) and the 1945 Indonesian Constitution and has roots in religious values and national culture and is sensitive to global change." This constitution also states that national cultural values are expressed in ideology, concepts, social systems, constitutions, and attitudes which represent the character of Indonesia as a nation. Hence, Indonesian folktales may be a possible agent to develop national cultural values that most primary school EFL teachers are willing to use as teaching material. The aim of developing basic competence in English at primary school level has been addressed by placing study of the language under 'local content' as expressed in Decree of the Minister of Education number 60/U/1993. This means that English is an optional subject for primary students. In practice, most primary schools in Indonesia choose English as part of the local content component of their curriculum. The government, through its National Standard Institution of Education, sets guidelines for the standard of competence for primary school graduates. These guidelines are based on standards the four language skills of speaking, writing, reading and listening. While primary school EFL teachers have a strong motivation to teach EFL, they also experience a number of barriers.

The idea that language learning can support mastery of local cultural knowledge may result from anxiety about possible loss of local cultural knowledge among younger Indonesians. Policy makers have tried to address this situation by requiring the study of local culture as a counter to the influences of globalization associated with the English language in Indonesia. Additionally, it may be that the numerous local languages and cultures of Indonesia can be united through the development of certain items of folklore with their inherent values that will be known by young people across the nation. This is seen as supporting the philosophy of 'unity in diversity' through EFL by using Indonesian folktales in translation. Hence, the EFL primary schoolteachers in implementing the government vision related to fostering the spirit 'unity in diversity' amongst the students and its effect on the students basic EFL competence is worth to question and to investigate. The finding of this research paper may come up with the suggestion that learning L2 can a means of learning the $\mathrm{C} 1$. It may oppose the premise saying learning a target language is always associated with its cultural background.

\section{Aim of study}

The aim of this study was to investigate the development of students' EFL skills through the use of Indonesian folktales in translation. Specifically, it was intended to describe and analyze the ways in which local cultural knowledge and English language ability developed in primary school students in Solo, Indonesia.

\section{Research Problem}

This present study involves the investigation of the government regulations and the reality of EFL teaching practice. The central government may have a vision such as preserving local cultural knowledge within Indonesian youths, but teachers may face difficulties in its implementation. In its regulation, English has not been set as an obligatory school subject for the students, yet another constitution recommended having school graduates who have sufficient basic English competence with its good local cultural knowledge as a means of maintaining the spirit of 'unity in diversity' within the youths.

\section{Research question}

1. How the primary EFL schoolteachers in Solo Indonesia implement the government policy for participating in fostering the spirit of 'unity in diversity' using Indonesian folktales in translation in their teaching practice?

2.

3. How the students perceive their EFL learning as means of acquiring local cultural knowledge to foster their spirit of 'unity in diversity'? 


\section{Language and culture teaching-learning process}

Kramsch (1995) noted that "language continues to be taught as a fixed system of formal structures and universal speech functions, a neutral conduit for the transmission of cultural knowledge. Culture is incorporated only to the extent that it reinforces and enriches. Not that it puts in the question, traditional boundaries of self and other." Where culture exists in every language, here she seems to emphasize that language can be a means of transferring cultural knowledge. Yet, the Indonesian context where English is a foreign language, learning and obtaining English language competence seems much enhanced using familiar cultural artifact such as Indonesian folktales in translation which is used as English language teaching-learning materials. It has been suggested that interculturalism is a more achievable goal than biculturalism in L2 study (Byram, 1998). This suggests that English language learners, particularly where English is a foreign language, are generally expected to learn and accept C2 as knowledge instead of accepting and internalizing C2 as norms and values relevant to their daily life.

Language and local culture preservation have often been of political interest in Indonesia. The decision to make English the first foreign language in Indonesia (Lauder, 2008) and the obligation for all academics and teachers to participate in preserving local culture embodied in its constitution and policy documents as described above. Indonesian observers have tended to view traditional literature, such as folktales, as vehicles for the development of a national character based on traditional values. Citraningtyas (2012) suggested that local content, particularly in the form of folktales such as Malin Kundang, might support the formation of national identity and develop students' national culture knowledge. Since this approach has been widely accepted in Indonesia, it is important to understand its impacts and effectiveness in achieving the goals of national education.

\section{Language, culture and identity}

Teaching language involves the teaching of culture as well. A number of authors have suggested that language and culture are inseparable (see, for example, Byram, 1998; Risager, 2005). Risager (2005), however, believes that L2 can be used to teach the culture of the learners. As Kramsch (1997) said that culture exists wherever the language is being learnt. Functioning EFL as the context for local cultural knowledge acquisition makes the students experience a negotiation between their own culture and the cultural knowledge of the target language. Being introduced to the target culture (C2) through teaching materials and class activities essentially helps the students to recognize their own identity that identity formation happened. This phenomenon fulfills the notion of sociological subject in the umbrella of identity concept as defined by Hall, Held, Hubert and Thompson (http://www9.georgetown.edu/faculty/irvinem/theory/Hall-IdentityModernity-1.pdf) and Hall (1996). In response to the growing society, Hall et al also said that one as a sociological subject should realize or aware of his/her being individual is formed in relation to "significant others" which give meaning to his/her existence within the society. In line with this idea, Woodward (1997) affirms that identity of oneself is not a 'unitary entity.' There is a process of 'dialogic circuit' connects one with others; one will be able to identify him/her identity by making relationship with other people. Values, meaning, and symbol as three aspects of culture of the upbringing effect the formation of one's identity (Hall, 1996). In this research, the process of learning local culture through EFL in class has made the students to interact, negotiate and define their own identity. Learning the target language has made the students are not only acquiring sufficient EFL basic skills but also using it to express their own local cultural knowledge as well as to receive information about a foreign culture.

On the other hand, many EFL textbooks lack explicit cultural content ( Sharif and Mohammadi, 2013). In Indonesia specifically, Hermawan and Noerkhasanah (2012) analyzes a number of primary school textbooks which they found to contain very limited local cultural information, despite having been written for use in the Indonesian context, and a considerable amount of implied assumptions about English language users. For this reason, the two EFL teachers - in this present research - look for external references such as Indonesian folktales in translation as an effort provide localculture-sensitive teaching materials. It is at the aim at fulfilling the Indonesian government vision to enrich the students with local cultural knowledge and to enhance the students' ability of socializing with the surroundings. Fortunately, it brings duel benefits for the students: enhancing the students' local cultural knowledge and facilitating as well developing the students' basic EFL competence. It seems that teaching-learning process using Indonesian folktales in translation is seen as social practice. The Indonesian government seems inviting the teachers to see literacy is no longer an autonomous skill but as social practice that is located in a larger institutional context: schools, home, community and possibly larger society (Norton, 2010). Ability of socializing with the surroundings needs students' ability to negotiate within him/her, with the culture of their upbringing, and the culture they are being exposed. Yet, Garuda Pancasila where 
the national motto 'unity in diversity' is inscribed lead the introduction to a cultural artifact such as Indonesian folktales may lead the students to recognize its national cultural identity. They may expect that they students may finally have a strong spirit 'unity in diversity' throughout their being as Indonesians.

Though national identity is not a visible concrete that it is addressed as imagined community (Anderson, 1991; Hall, 1996; Norton \& Kanno, 2003), national cultural identity is a significant element to the existence of a nation. It is apparently the reason of EFL primary school teachers to incorporate Indonesian folktales in translation as their EFL teaching materials to introduce local cultural artifact and to enhance the sense of belonging to local culture. Indonesian folktales as representation of cultural group can be an important part to compose a national culture. Indonesian folktale as a representation of national culture latter constructs national identity, as it is able to connect people from the past, present and future through its texts (though it is initially known as oral literature) and language.

\section{EFL teaching in Solo, Central Java}

The government of Solo, Central Java, has implemented the national requirements for local content teaching by placing three subjects into their local content curriculum. They are Javanese, the local language which is the first language of a significant majority of residents in the region; transitional arts of the region; and English language. Given these three options, most primary schools have chosen English as the local content subject they will teach. However, the requirement that whatever specific subject is taught as part of the local content curriculum must embody the local culture of the region means that EFL teachers have tended to use teaching materials which are culturally appropriate for the context, such as translated Indonesian folktales. The central government does not instruct schools how to teach a particular subject. For this reason, curriculum construction is based on teachers' own interpretation of the rules. In Solo, this has led to the focus on Indonesian folktales in translation as one source of learning material for the study of EFL at primary school level.

\section{Methods}

This case study was conducted in Solo, Central Java Indonesia. It involved two EFL teachers and twelve students from two primary schools, one public and one religious. Semi-structured interviews were conducted with the two teachers who were also required to provide the lesson plans related to their EFL teaching using Indonesian folktales in translation. These lesson plans were also used as the basis for conducting further interviews with the teachers.

The two EFL teachers came from two primary schools with different institutional background. It was expected that these differences in context might impact on the teachers' approach to EFL and their perceptions about the inclusion of local cultural content material in language teaching.

Classes always involve teachers and students in teaching-learning process. Thus, obtaining the students' opinion on the teaching-learning process is the other important step in collecting the data for this qualitative research. The researcher as the interviewer also interviewed the twelve students (six students from each school) to grasp the students' response and opinion on their EFL classes particularly related to the use of Indonesian folktales in translation to learn EFL and its influence to their spirit of "unity in diversity" as part of their cultural identity. Pictures of folktales - Indonesian and western folktales - were considered the appropriate ones to deal with the students who are at the age of 10-12 years old. As Piaget's theory of psychological development - cognitive stages - they are at the age of connecting imagination and reality or thinking abstractly and making judgment of concrete phenomena (http://www2.honolulu.hawaii.edu/facdev Iguidebk/teachtip/piaget.htm). Pictures are expected to stimulate their imagination and to relate it with contexts (content of folktale texts, class activities and society). Pictures of folktales worked well in engaging and attracting the students' attention that they seemed at ease to arrive with their expressions and responses to questions during the interviews.

\section{Teaching EFL through Indonesian Folktales in Translation to foster the spirit of 'unity in diversity'}

Both teachers interviewed as part of this study had difficulty reconciling the available teaching materials with the requirement for local content teaching. Both noted incongruities between the textbooks they were supposed to use and their needs for teaching materials. Textbooks, they explained, were chosen by a group of stakeholders that includes teachers, principals, parents of students, and the school committee. For this reason, they had limited ability to influence the choice of materials and were required to use the texts chosen in this manner. Ms Abia, the teacher at the Islamic private school, commented that she had to adjust in order to accommodate her students' needs, fulfill the local content requirement, and also address contextual issues arising from the institutional background of the school. The fact that it is 
an Islamic school means that the teaching and learning process requires the inclusion of specific values and approaches that fit with the school's orientation.

Nonetheless, both teachers felt that having a textbook as a basis for teaching was valuable and desirable. In their view, a textbook provides an important reference for both teachers and students. Mr Joko, the public school teacher, commented that he feels comfortable relying on a textbook and this makes his preparation easier and more effective. This view is in line with observations in other locations (see, for example, Cunningsworth, 1995; Tok, 2010).

Despite the practicality of textbooks, the two teachers noted weaknesses in their EFL textbooks. Ms Abia noted that the textbook focuses on grammatical use, but this approach is not really appropriate for her primary students. She tends to focus on other teaching methods such as reading as an alternative for students. The ongoing finding of this research, particularly the textual analysis on the EFL textbook supports those teachers' finding that the textbook gives more interest on grammatical concern rather than contextual teaching materials such as Indonesian folktale is not available in the textbook. Therefore, the EFL teachers believe the most effective way to address the shortcoming of the textbooks is through the use of supplementary material taken from other sources.

Ms Abia and Mr Joko look for external references to fulfill their teaching needs. Mr Joko sometimes involves his students in this. He has asked students to look for teaching materials on the internet and then has developed class assignments based on their findings. Ms Abia has more time for her class to engage in learning more activities than the public school provides. In addition to reading and translating texts, she also uses facial expressions and games based on local culture as teaching materials.

The EFL teachers use Indonesian folktales in translation as a medium for teaching EFL. While their main reason for this is the lack of suitable material in the textbook, the two teachers also have additional issues they need to address. Ms Abia, for example, has to consider Islamic values in developing teaching materials. The reading approach that she uses to teach English requires that her students engage in text exploration. Western folktales, such as Cinderella, for example, which is presented in the textbook as a western story for students to study, tend to contain incongruent cultural values. Prince Charming and Cinderella dancing and embracing in public is not acceptable in the Islamic context. Nonetheless, she does explain to her students that such behavior is considered appropriate in an English-speaking setting.

Both teachers are also concerned to promote 'unity in diversity' (Bhinneka Tunggal Ika), as the Indonesian national philosophy. They feel their students are proud to be Indonesian and believe that this aspect of their identity should be fostered through exposure to the diverse culture, values, and characteristics of the nation. Ms Abia, for example, explained that he preferred to teach the story of Bathara Kala which comes from Java or Mr Joko who preferred to teach the story of Malin Kundang which comes from West Sumatera, rather than Cinderella, because the story is Indonesian in origin and because this is a way of contributing to the preservation of local culture.

They are aware of the significance of teaching local cultural knowledge in developing in their students a sense of belonging and an awareness of local cultural heritage. They see this as supporting their students' cultural identity and allowing them to find their place in the increasingly globalized world. Ms Abia notes that students tend to master English more readily and learn it better when they understand the cultural content being presented. They are happy, she says, when they find something they recognize in a text written in English. She places great importance on the teaching of their own culture to students. They need to know about western culture but be awareness and participate in their own.

The two EFL teachers recognize the need for students' understanding of local culture to encompass their own regional culture (in this case Javanese) but also include an understanding of the broader cultural traditions of Indonesia. Mr Joko explains that his goal of introducing Indonesian folktales is to introduce a variety of Indonesian cultures from different part of the country. The diversity of Indonesian culture of culture will become a familiar to the students and they will be moire able to participate in the Indonesian national mainstream.

In this way, the use of a variety of items from different Indonesian cultures may encourage the formation of national identity. The students in Ms Abia and Mr Joko's classes take pride in wearing traditional clothing of their region. Idam, one of the public school students, for example, expresses his identity as an Indonesian by wearing of Javanese clothes. The ability to describe cultural matters in English in a case like this might give the speaker an additional channel through which his personal identity might be expressed.

The internalization of culture through the teaching of Indonesian folktales in EFL can be a means of forming national identity. Most of the students who took part in this study (eight of twelve students) say that they feel more familiar with Indonesian folktales than western ones. The content of the stories, the clothing of the characters which reflect Indonesian customs and cultural values similar to those held by people they know contribute to this. These EFL classes are not the only place where these students can engage in discourse that encourages the internalization of Indonesian 
culture; this takes place in Indonesian classes as well as classes in the local language. Systematic exposure to Indonesian culture creates the possibility of cultural internalization by the students. This internalization involves negotiation within the individuals, negotiation between the culture where they are being raised, and new cultural values they are exposed to. Students are then able to identify themselves as members of a specific cultural and will ideally use their knowledge to support and maintain their own local culture alongside the national culture and the globalized world culture, which is the aim of the national educational process in Indonesia.

\section{Conclusion}

This study shows that the use of Indonesian folktales in translation as material for EFL teaching at primary level in Solo, Indonesia, has benefit for language learning. The teachers involved believe that familiarity with the content of such stories facilitates students' mastery of English and makes them more comfortable using a new language. This outcome is a bonus, as the primary impetus for using such materials was originally to fulfill government requirements that local cultural knowledge be included in local content curriculum of which English is a part of primary school level. Nonetheless, the teachers involved in this study are satisfied that this practice goes beyond simply satisfying that requirement and has real benefit for language learning. These realities show that learning the target language (L2) can be a means of learning C1 (culture of the language learners) instead of associating with and emphasizing on learning C2 (culture of the target language).

Despite this, the teachers note the difficulty of obtaining the required material and have identified various weaknesses in the textbooks they normally use. These books are prescribed by their schools and tend not to contain the required local cultural material. This remains a concern for these teachers, although both feel there is broader value in the approach of using Indonesian folktales in translation in EFL classes and there are concrete benefits for students both in terms of language mastery as well as in terms of personal development of a regional and national identity.

\section{References}

Anderson, B. (2006). Imagined communities. London, United Kingdom: Verso Books.

Kaplan, R. B., \& Baldauf JR, R. B. (2003). Language and language-in-education planning in the Pasific Ba (Vol. 2). Dordrecht, Netherland: Kluwer academic publishers.

Bjork, C. (2004). Decentralization in education, institutional culture and teacher autonomy in Indonesia. International review of education, $50,245-262$.

Byram, M. (1998). Cultural identities in multilingual classrooms. In J. Cenoz \& F. Genesee (Eds.), Beyond bilingualism (pp. 96-116). Clevedon, England: Multilingual Matters.

Crystal, D. (2003). English as a global language (2nd ed.). UK: Cambridge University Press.

Cunningsworth, (1995). Choosing your coursebook. Oxford, England: Heinemann English Language Teaching.

Hall, S. (1997). The work of representation in Representation: cultural representations and signifying practices.(Ed.) Hall. S. 1-74.

Harsono, Y.M. (2006). English language teaching in Indonesia: facts, problems and possible solution. English. edu journal., 5 (2).

Hermawan, B \& Noerkhasanah, L. (2012). Traces of cultures in English textbooks for primary education. Indonesian Journal of Applied Linguistics. VOI 1 (2), 49-61.

Krammsch, C. (1995). The cultural component of language teaching language, culture and curriculum. Language, culture and curriculum. Vol. 8 (2), 83-92.

Kramsch, C. (2012). The cultural component of language teaching. http://zif.spz.tu-darmstadt.de/jg-01-2/beitrag/kramsch2.htm. Retreived: 2nd Oct 2012.

Lauder, A. (2008). The status and function of English in Indonesia: a review of key factors. Makara Social Humaniora. Vol. 12 (1), 9-20.

Mantiri, O. (2006). ELT in Indonesia: what culture should be taught? elt-indonesia.blogspot.com/ 2006/culture-sensitive-approach-inelt.html.

McKay, S.L. (2000). Teaching English as an international anguage:implications for cultural materials in the classroom. TESOL journal, Vol. 9 (4), 7-11.

Nault's (2006). Going global: rethinking culture teaching in ELT contexts. Language, culture and curriculum. Vol. 19 (3), $314-328$.

Risager, K. (2005). Languaculture as a key concept in language and culture teaching in The Consequences of mobility. (Ed.) Preisler, B., Fabricious, A., Haberland, Hartmut., Kjaerbaeck, S. \& Risager, K. Roskilde: Roskilde University, Dept. of language and culture, 185- 196.

Risager. K. (2007). Language and culture pedagogy: from national to a transnational paradigm. UK: Multilingual Matters Ltd.

Saragih, B. BT. (2012). SBY reminds of importance of 'Bhinneka Tunggal Ika'. Jakarta Post. 12 ${ }^{\text {th }}$ August 2012, Thursday. http://www.thejakartapost.com/news/2012/08/02/sby-reminds-importance-bhinneka-tunggal-ika.html

Sharif and Mohammadi. (2013). Cultural, national identity, and globalization between the lines of reading comprehension texts in Iran. Elixir Ling. \& Trans. 56, 13452-1345. 
Smith, J. \& Wiese, P. (2006). Authenticating children's literature: raising cultural awareness with an inquiry-based project in a teacher education course. Teacher quarterly, 69-87.

Sugirin, Sudartini S, Suciati \& Lusi Nurhayati. (2011). A study on cultural intergration in the English textbooks for junior high schools. Litera, Journal of language, literature and applied teaching, Faculty of Language and Arts, State University of Yogyakarta Indonesia. Vol 10 (2), 235-246.

Tok, H. (2010). TEFL textbook evaluation: from teachers' perspectives. Educational Research and Review Vol. 5 (9), $508-517$.

Woodward. K. (1997). Identity and difference. England: Sage Publications Ltd. 
